\title{
Endonasal Endoscopic Technique in Management of Juvenile Nasopharyngeal Angiofibroma - Our Experience
}

\author{
ID Singh ${ }^{1 *}$, Vikas Gupta ${ }^{1}$, Sunil Goyal ${ }^{1}$, Manoj Kumar ${ }^{1}$ and Anubhav Singh ${ }^{2}$ \\ ${ }^{1}$ Department of ENT - Head Neck Surgery, Command Hospital, India \\ ${ }^{2}$ Department of ENT, Armed Forces Medical College, India
}

Submission: January 30, 2017; Published: February 06, 2017

*Corresponding author: I D Singh, Asst Prof, Department of Otolaryngology Head \& Neck surgery, Command Hospital (Southern Command), Pune, India 411040, Tel: +91-7767834137; Email: dridsingh@hotmail.com

\begin{abstract}
Juvenile nasopharyngeal angiofibroma (JNA) is benign \& locally aggressive vascular tumorprimarily affecting adolescent boys. Intraoperative blood loss is reduced by preoperative embolization and should be done before 24 to 48 hours of surgery. Preoperative angiography at the time of embolization can help to identify the feeding vessel and any contribution from ICA. The exact etiology of JNA is not known. Most of the JNAs can be resected via an endoscopic endonasal approach with decreased morbidity, decreased blood loss and less recurrence. This article highlights and emphasizes on role of endoscopic technique in JNA surgery and our experience in managing such cases. 5 cases have been highlighted here who underwent successful en bloc removal of the tumour via endoscopic endonasal approach.

Keywords: Juvenile nasopharyngeal angiofibroma; Endonasal endoscopic resection

Abbreviations: JNA: Juvenile Nasopharyngeal Angiofibroma; PPF: Pterygopalatine Fossa; ECA: External Carotid Artery; CT: Computed Tomography
\end{abstract}

\section{Introduction}

Juvenile nasopharyngeal angiofibroma (JNA) is a benign vascular tumor, the etiology of which remains unknown [1]. It arises from the tissues around the sphenopalatine foramen. Although typically slow growing, the senonencapsulated tumors are locally aggressive, with the potential for intracranial or intraorbital extension. Advanced may reach into the pterygopalatine fossa (PPF) [2]. Intracranial extension occurs in approximately $10 \%$ to $20 \%$ of patients [3,4]. JNAs typically derive their blood supply from the ipsilateral internal maxillary artery, a branch off the external carotid artery (ECA). However, bilateral supply and communication with the internal carotid are relatively common [4].

JNAs are rare, representing a mere $0.5 \%$ of head and neck tumours and occur almost exclusively in adolescent male patients. The most common presenting symptoms are epistaxis and progressive nasal obstruction. Other presenting symptoms include nasal discharge, pain, sinusitis, otologic symptoms, visual loss, facial deformity, facial hypoesthesia, diplopia (from cranial nerve compression or from direct orbital compression), and proptos is due to extension of the tumour into the orbit $[4,5]$.

Preoperative embolization is typically performed 24 to 48 hours before scheduled surgery to decrease intraoperative bleeding. Amongst the options available for management of JNA, surgical resection is the definitive treatment modality for JNA $[4,5]$. There are various staging techniques described for JNA which includes open surgical approaches and endoscopic endonasal approaches keeping in mind the extent of tumor. There is a growing trend towards endoscopic management of tumours limited to the nose, PNS and pterygopalatine fossa owing to better instruments and technique. The authors report successful endoscopic management of five cases of JNA in this case series.

\section{Surgical technique}

All cases underwent Digital subtraction angiography and preoperative embolization was performed 48 hours prior to surgery. Endonasal endoscopic excision of JNA`s were 


\section{Global Journal of Otolaryngology}

done using $4 \mathrm{~mm} 0$ degree, 30 degree nasal endoscopes and multiangle sinuscope. Fine bipolar cautery was used to assist in removal of posterior inferior turbinate and inferior middle turbinate. Gun bipolar cautery and vascular clip was used for sphenopalatineartery ligation or any other vessel ligation like posterior septal branch of sphenopalatine artery. Microdebrider drills both straight and curved were used for drilling medial maxilla, posterior wall of maxillary sinus, pterygoid base and basisphenoid regions. Second stage septoplasty was done on the opposite side endoscopically in two cases.

First theposterior and along maxillary sinus portion ofinferior turbinate was removed for better access to medial maxillectomy. Inferior part along with ground lamella of middle turbinate removed to approach sphenopalatine foramen. Uncinate and Bulla ethmoidal is removed. Medial maxillectomy was performed and posterior wall of left maxillary sinus removed. Sphenopalatine foramen was identified using the landmarks of middle turbinate lateral attachment and ethmoidal is crest of maxillary sinus. Pterygopalatine fossa and sphenopalatine foramen were opened widely by careful drilling with angled diamond burrs and bone nibblers. Internal maxillary artery was indentified and exposed till its sphenopalatine branch. The most medial part of internal maxillary artery and sphenopalatine artery either ligated with vascular clips or cauterised by bipolar cautery. Posterior septum was also removed to allow wider approach and delivery of JNA.
Anterior and posterior ethmoidectomy done exposing roof of posterior ethmoid upto frontal recess and wide sphenoidotomy performed exposing planum sphenoidale and its lateral wall. Tumour is dissected off with the help of bipolar cautery from adjacent structures; septum, sphenoid rostrum, lateral nasal wall, Sphenopalatine fossa, Pterygopalatine fossa, skull base, and nasopharynx and was pushed into oropharynx and delivered orally. Sphenoid rostrum, basisphenoid and pterygoid base were drilled. Hemostasis was confirmed and bilateral nasal cavities were packed. Nasal pack was removed on $2^{\text {nd }}$ post-operative day and regular nasal endoscopic toilet was done. Nasal saline irrigation and decongestant nasal drops were started (Figures 1-7) (Table 1).

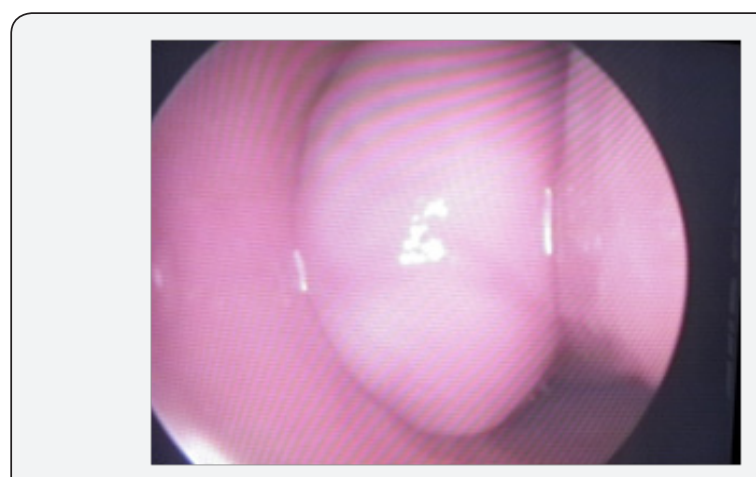

Figure 1: Nasal endoscopic assessment showing pale fleshy mass filling up left nasal cavity.

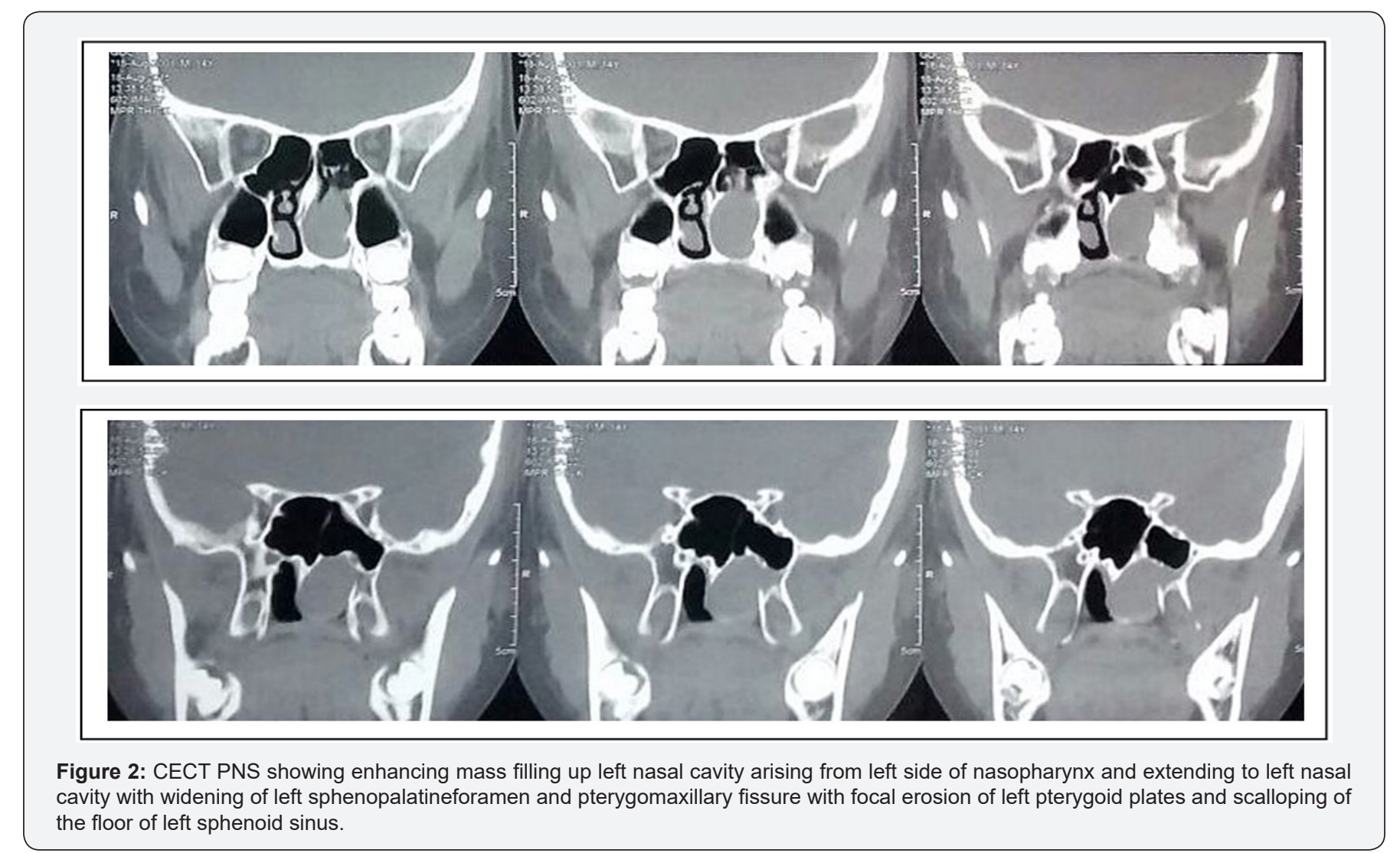




\section{Global Journal of Otolaryngology}

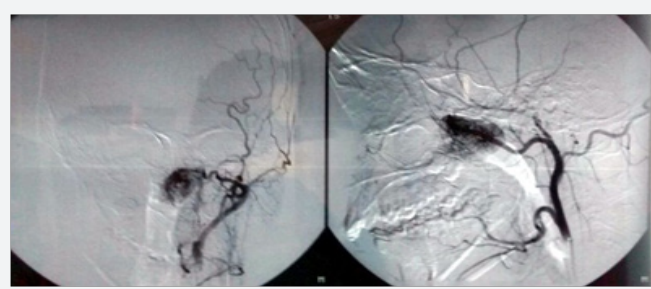

Figure 3: Showing Digital substraction angiography depicting major vascular supply of JNA arising from left internal maxillary artery.
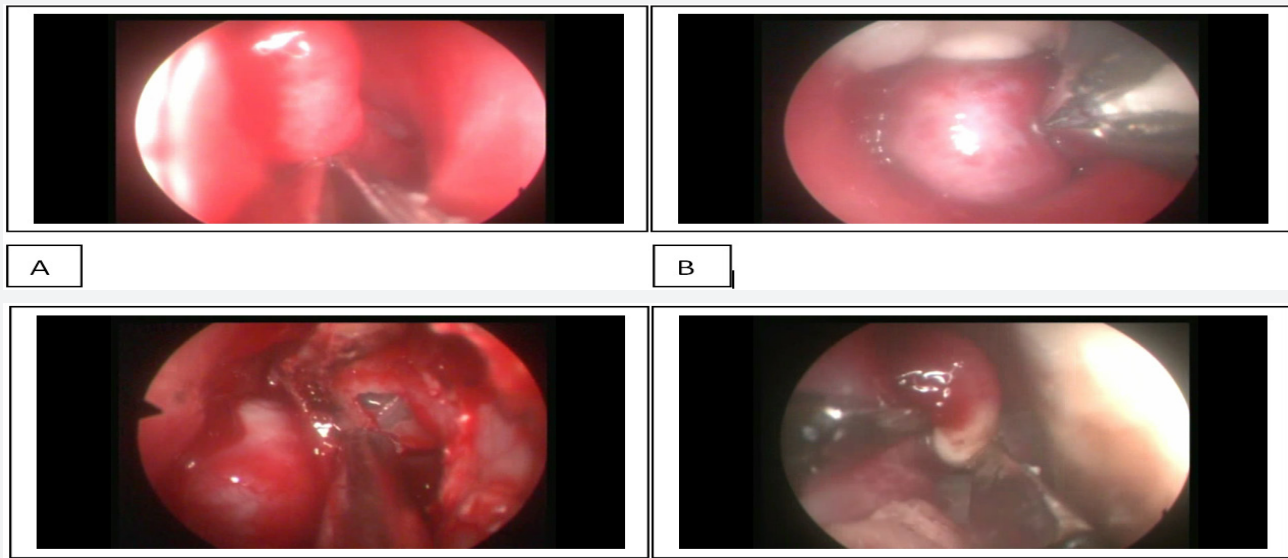

$$
\text { c }
$$

$\mathrm{D}$

Figure 4: Intraoperative pictures-
A: Dissection of angiofibroma from lateral wall,
B: Dissection from middle turbinate,
C: Partial middle turbinectomy,
D: Middle meatalantrostomy.

Figure 5: Intraoperative pictures-
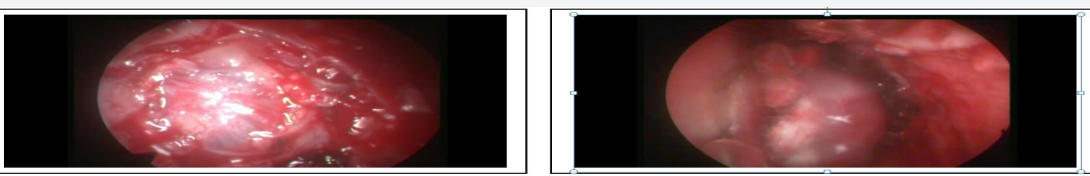

A

B
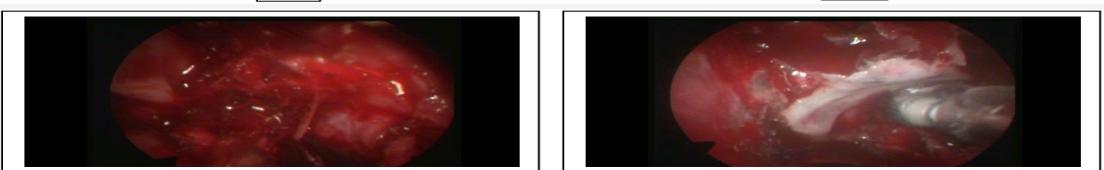

$\mathrm{C}$

\section{$\mathrm{D}$}

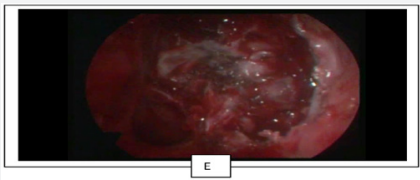

A: Unroofing of angiofibroma from sphenoid sinus,

B: Removal of posterior part of septum,

C: Separating angiofibroma from its pharyngeal adhesions,

D: Drilling of sphenopalatine foramen and sphenoid rostrum,

E: Nasal cavity after complete removal of JNA. 


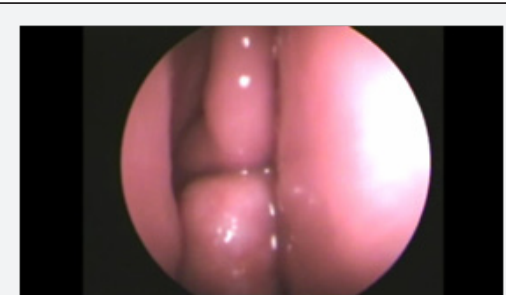

Figure 6: Showing fleshy mass arising filling up right nasal cavity.

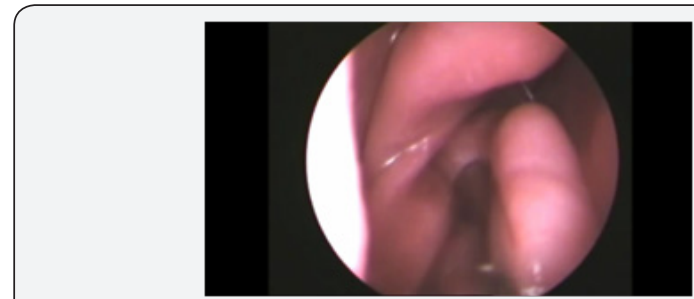

Figure 7: Showing attachments of nasal mass from middle turbinate and septum.

Table 1: Details of Patients.

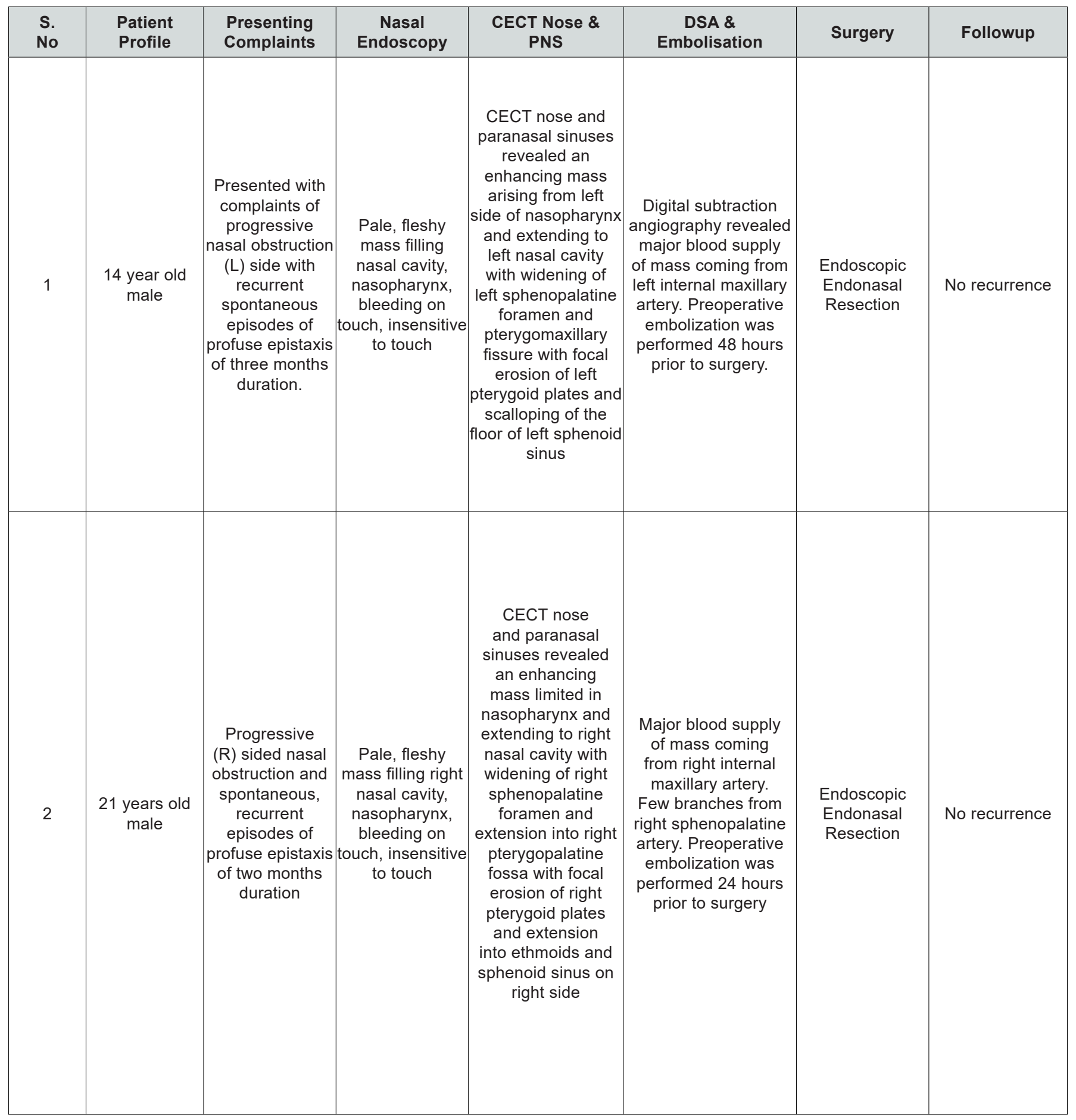




\begin{tabular}{|c|c|c|c|c|c|c|c|}
\hline 3 & $\begin{array}{l}18 \text { years old } \\
\text { male }\end{array}$ & $\begin{array}{l}\text { Progressive } \\
\text { nasal } \\
\text { obstruction } \\
\text { (L) sided with } \\
\text { recurrent } \\
\text { profuse } \\
\text { epistaxis of } \\
\text { three months } \\
\text { duration }\end{array}$ & $\begin{array}{l}\text { Pale, fleshy } \\
\text { mass filling } \\
\text { the left } \\
\text { nasal cavity, } \\
\text { nasopharynx, } \\
\text { bleeding } \\
\text { on touch, } \\
\text { insensitive to } \\
\text { touch }\end{array}$ & $\begin{array}{l}\text { CECT nose } \\
\text { and paranasal } \\
\text { sinuses revealed } \\
\text { an enhancing } \\
\text { mass arising } \\
\text { from left side of } \\
\text { nasopharynx and } \\
\text { extending to left } \\
\text { nasal cavity with } \\
\text { widening of left } \\
\text { sphenopalatine } \\
\text { foramen, deviation } \\
\text { of septum towards } \\
\text { opposite side, } \\
\text { extension into } \\
\text { left ethmoid and } \\
\text { sphenoid sinus. }\end{array}$ & $\begin{array}{l}\text { Major blood supply } \\
\text { of mass coming from } \\
\text { left internal maxillary } \\
\text { artery. Preoperative } \\
\text { embolization was } \\
\text { performed } 48 \text { hours } \\
\text { prior to surgery }\end{array}$ & $\begin{array}{c}\text { Endoscopic } \\
\text { Endonasal } \\
\text { Resection }\end{array}$ & No recurrence \\
\hline 4 & $\begin{array}{l}16 \text { years old } \\
\text { male }\end{array}$ & $\begin{array}{l}\text { Presented with } \\
\text { complaints of } \\
\text { progressive } \\
\text { nasal } \\
\text { obstruction } \\
\text { (L) side and } \\
\text { recurrent, } \\
\text { spontaneous } \\
\text { profuse } \\
\text { epistaxis of } \\
\text { six months } \\
\text { duration }\end{array}$ & $\begin{array}{l}\text { Pale, fleshy } \\
\text { mass filling } \\
\text { nasal cavity, } \\
\text { nasopharynx, } \\
\text { bleeding } \\
\text { on touch, } \\
\text { insensitive to } \\
\text { touch }\end{array}$ & $\begin{array}{l}\text { CECT nose and } \\
\text { paranasal sinuses } \\
\text { revealed an } \\
\text { enhancing mass } \\
\text { in nasopharynx } \\
\text { and extending } \\
\text { to left nasal } \\
\text { cavity with } \\
\text { widening of left } \\
\text { sphenopalatine } \\
\text { foramen and } \\
\text { pterygomaxillary } \\
\text { fissure, minimal } \\
\text { extension into } \\
\text { infratemporal } \\
\text { fossa, extension } \\
\text { into ethmoids and } \\
\text { sphenoid sinus } \\
\text { left side with focal } \\
\text { erosion of left } \\
\text { pterygoid plates } \\
\text { and deviation of } \\
\text { septum towards } \\
\text { opposite side }\end{array}$ & $\begin{array}{l}\text { Digital subtraction } \\
\text { angiography } \\
\text { revealed major } \\
\text { blood supply of } \\
\text { mass coming from } \\
\text { left internal maxillary } \\
\text { artery. Few branches } \\
\text { from sphenopalatine } \\
\text { artery. Preoperative } \\
\text { embolization was } \\
\text { performed } 48 \text { hours } \\
\text { prior to surgery }\end{array}$ & $\begin{array}{c}\text { Endoscopic } \\
\text { Endonasal } \\
\text { Resection }\end{array}$ & No recurrence \\
\hline 5 & $\begin{array}{l}19 \text { years old } \\
\text { male }\end{array}$ & $\begin{array}{l}\text { Progressive } \\
\text { nasal } \\
\text { obstruction } \\
(R) \text { sided } \\
\text { with recurrent } \\
\text { episodes of } \\
\text { epistaxis of } \\
\text { two months } \\
\text { duration }\end{array}$ & $\begin{array}{l}\text { Pale, fleshy } \\
\text { mass filling } \\
\text { nasal cavity, } \\
\text { nasopharynx, } \\
\text { bleeding } \\
\text { on touch, } \\
\text { insensitive to } \\
\text { touch }\end{array}$ & $\begin{array}{l}\text { CECT nose } \\
\text { and paranasal } \\
\text { sinuses revealed } \\
\text { an enhancing } \\
\text { mass arising } \\
\text { from right side of } \\
\text { nasopharynx and } \\
\text { extending to right } \\
\text { nasal cavity with } \\
\text { widening of right } \\
\text { sphenopalatine } \\
\text { foramen with focal } \\
\text { erosion of left } \\
\text { pterygoid plates } \\
\text { and scalloping } \\
\text { of the floor of left } \\
\text { sphenoid sinus. } \\
\text { Anterior bowing } \\
\text { of posterior wall } \\
\text { of right maxillary } \\
\text { sinus. }\end{array}$ & $\begin{array}{l}\text { Digital subtraction } \\
\text { angiography } \\
\text { revealed major } \\
\text { blood supply of } \\
\text { mass coming from } \\
\text { left internal maxillary } \\
\text { arteryPreoperative } \\
\text { embolization was } \\
\text { performed } 24 \text { hours } \\
\text { prior to surgery }\end{array}$ & $\begin{array}{c}\text { Endoscopic } \\
\text { Endonasal } \\
\text { Resection }\end{array}$ & No recurrence \\
\hline
\end{tabular}




\section{Discussion}

Juvenile angofibroma has been recognised since the times of Hippocrates. Hippocrates describes a lesion similar to JNA which he removed by a midline nose splitting incision. The most common presenting symptoms of JNA patients are unilateral nasal obstruction (91\%) and epistaxis (63\%). Other symptoms are -rhinorrhoea, pain, facial swelling, otologic symptoms such as unilateral conductive hearing loss due to development of otitis media with effusion and ocular symptoms of proptosis and diplopia. Symptoms are generally present for 6 months to a year before the patient is diagnosed [5,6]. All our cases presented quite early before development of orbital of intracranial complications. In all the cases, the disease was limited to nose, nasopharynx, PNS and pterygopalatine fossa with minimal extension into infratemporal fossa in one case. JNA has a male preponderance with ages of 10 and 25 years, with a median age at diagnosis of 15 years [6].

JNAs are characterized grossly as well-defined, mucosalized, and red to pale masses filling the nasal cavity and extending till nasopharynx. Histologically, the tumor has two main components: spindle shaped cells embedded in a collagen matrix and a complex vascular supply that vary in size from capillaries to large venous channels. Characteristically, these vessels lack elastic fibers and smooth muscles and have vascular walls that vary in thickness. These features account for the tendency of these tumors for easy hemorrhage [7]. JNAs possess multiple hormone receptors, including testosterone, dihydrotestosterone, and androgen [8].

Computed tomography (CT) and MRI are both crucial for the proper preoperative evaluation of angiofibromas. Advantages of CT scan are better delineation of bony details of the skull base, including bony erosion, and depth of invasion into the bone of the sphenoid sinus, which is a main predictor of recurrence. The extent of invasion into the bone of the sphenoid is difficult to determine intraoperatively, and this may lead to a likelihood of residual tumor and recurrence $[9,10]$. The pathognomonic radiologic feature of JNA is "Holman-Miller sign", anterior bowing of the posterior maxillary wall, mass originating at the sphenopalatine foramen and erosion of the mass into the pterygomaxillary fossa, sphenoid sinus, and infratemporal fossa $[9,10]$. MRI is advantageous in form that it highlights soft tissue elements of the tumor and assesses the relation of the tumor to critical structures such as the internal carotid artery, cavernous sinus, and pituitary gland. In addition to preoperative evaluation, MRI also helps in appreciation of recurrence and residual tumors $[9,11]$. MRI also helps to differentiate between involvements of a sinus by tumour vs collection of secretions due to blockage of drainage of the sinus.

Further confirmation of the JNA diagnosis is usually done by digital subtraction angiography, which also is a part of treatment in form of embolization. Angiography gives information on the specific blood supply of the tumor. Distal branches of the internal maxillary artery, a branch of the external carotid, provide the major blood supply for most JNAs, but, as tumors grow, they may also develop vascular supply from branches of the ipsilateral internal carotid artery and contralateral external carotid artery [12]. Angiography causes the tumour to shrink and there is a decrease in intraoperative bleeding of up to $60 \%$.

Several staging systems for nasopharyngeal angiofibromas are in vogue, all based on extent of the tumor. The three most followed staging systems are - Andrews' (modified Fisch) [13], Chandler's [14], and Radkowski's [15]. JNAs are classified depending on the extension of tumor and amount of intracranial extension. Though, at present, there is no single universally adopted classification system [13]. As one considers an anterior endonasal approach, it is crucial to bear in mind the relative anatomic position of the origin, as well as the spread of a JNA. Understanding the relative spread outside the PPF for surgical dissection requires a comprehensive grasp of - anatomy of the pterygopalatine fossa, JNA's origin and propensity of JNAs to spread directly through natural anatomic pathways rather than through destructive invasion.

Common routes of direct extension beyond the pterygopalatine fossa include extension into - orbit via the infraorbital fissure, infratemporal fossa via the pterygomaxillary fissure, middle cranial fossa either by through the infraorbital fissure to theforamen rotundum or through the foramen ovale from the infratemporal fossa and anterior cranial vault via direct extension through the ethmoid cavity [4].

At our institution, patients with JNA are typically worked up starting with diagnostic nasal endoscopy followed by imaging which are followed by in depth discussion between Otorhinolaryngology and interventional radiology team. The decision for angiography and transcatheter embolization is taken and is performed 24-48 hours before the planned operation. A standard array of laboratory studies are obtained as part of the preoperative workup, including biochemistry panel, complete blood cell count, coagulation panel, and a type and cross match for two units of packed red blood cells. Surgical resection is always performed within 48 hours of embolization to minimize revascularization as well as to limit the post embolization inflammatory response.

Typically, the nasal portion of the tumor is first be debulked to provide better access to the sinonasal structures Debulking can be done with bipolar cautery and microdebridor. An uncinectomy and wide middle meatal antrostomy is performed. Enlargement of the middle meatal antrostomy is done until the posterior wall of the maxillary sinus is clearly visible. It is our usual practise to remove the posterior part of nasal septum to allow better visualisation and access from the opposite nasal cavity. Then a total ethmoidectomy is performed and identification of the sphenoid rostrum is done. Sphenoidotomy 
is then performed to ensure that tumour does not extend into the sphenoid. Then isolation and clip/ligatation/cauterisation of the sphenopalatine artery is done lateral to the tumour. After ensuring that all attachments and adhesions of tumor have been resected. Tumor is then delivered via the nasopharynx and out the mouth. Entire mucosal area that was involved with tumour is then inspected. It is our usual practise to drill sphenopalatine area, basispenoid and sphenoid rostrum to prevent recurrence. Meticulous haemostasis is then achieved and both nasal cavities are packed with haemostatic material.

Nasal packs are removed on postoperative day two. The patient is then started on nasal saline sprays for one week and is transitioned to nasal saline irrigations thereafter. Routinely, the patient is discharged home on this irrigation regimen with instructions to refrain from nose blowing and strenuous activity, including instructions regarding bowel regimens in the setting of constipation. If patients present with a bleed in the outpatient setting, they are instructed to report immediately to the emergency room.

In the postoperative setting, patients undergo sinonasal endoscopy with debridement in the clinical setting at approximately 2 weeks and again at 4 to 6 weeks. The postoperative cavity is usually well mucosalized by 6 to 12 weeks after surgery. Follow-up in the first year is usually every 3 months. Future imaging studies usually consist of MRI at 1 year and clinical follow-up thereafter for five years. Average blood loss is nearly uniformly described as lower than that with comparable open surgical approaches, with average blood loss ranging from $168 \mathrm{~mL}$, in series with only low-stage tumors, to $1500 \mathrm{~mL}$, in series with high-stage (Radkowski stage IIIa or greater) tumors. Average blood loss across studies reporting this data was $445 \mathrm{~mL}$. These numbers compare favourably with generally quoted numbers for open approaches; in a series by Hackman and colleagues [16]. Outcomes in our centre have been comparable with these results.

\section{Summary and Conclusion}

JNA remains elusive regarding its genetics and pathogenesis. Further research is mandatory that may lead to less invasive and more specific targeted therapies as well as better endoscopic technique. It is clinically apparent now that resection of these tumors no longer necessitates a large, cosmetically morbid operation. Endoscopic skull base tumor surgery and endoscopic skull base reconstructions now allow for resection of advancedstaged JNAs at experienced centres. Preliminary outcome data are promising, with trends toward decreased blood loss, length of hospital stay, morbidity, and potentially cost. The panoramic visualization of the endoscopic endonasal approach provides more precision when dissecting critical structures. In case of any CSF leak happening inadvertently during surgery, endoscopic technique allows repair of the defect under direct visualisation.

\section{Reference}

1. Coutinho-Camillo CM, Brentani MM, Nagai MA (2008) Genetic alterations in juvenile nasopharyngeal angiofibromas. Head neck 30(3): 390-400.

2. Mattei TA, Nogueira GF, Ramina R (2011) Juvenile nasopharyngeal angiofibroma with intracranial extension. Otolaryngol Head Neck Surg 145(3): 498-504.

3. Gullane PJ, Davidson J, O'Dwyer T, Forte V (1992) Juvenile angiofibroma: a review of the literature and a case series report. Laryngoscope 102(8): 928-933.

4. Zanation AM, Mitchell CA, Rose AS (2012) Endoscopic skull base techniques for juvenile nasopharyngeal angiofibroma. Otolaryngol Clin North Am 45(3): 711-730.

5. Blount A, Riley KO, Woodworth BA (2011) Juvenile nasopharyngeal angiofibroma. Otolaryngol Clin North Am 44(4): 989-1004.

6. Glad H, Vainer B, Buchwald C, Petersen B, Theilgaard S, et al. (2007) Juvenile nasopharyngeal angiofibromas in Denmark 1981-2003: diagnosis, incidence, and treatment. Acta otolaryngol 127(3): 292-299.

7. Beham A, Fletcher C, Kainz J, Schmid C, Humer U (1993) Nasopharyngeal angiofibroma: an immunohistochemical study of 32 cases. Virchows Arch A Pathol Anat Histopathol 423(4): 281-285.

8. Hwang HC, Mills SE, Patterson K, Gown AM (1998) Expression of androgen receptors in nasopharyngeal angiofibroma: an immunohistochemical study of 24 cases. Mod Pathol 11(11): 11221126.

9. Lloyd G, Howard D, Lund V, Savy L (2000) Imaging for juvenile angiofibroma. J Laryngol Otol 114(09): 727-730.

10. Lloyd G, Howard D, Phelps P, Cheesman A (1999) Juvenile angiofibroma: the lessons of 20 years of modern imaging. J Laryngol Otol 113(02): 127-134.

11. Herman P, Lot G, Chapot R, Salvan D, Huy PTB (1999) Long-term followup of juvenile nasopharyngeal angiofibromas: Analysis of recurrences. Laryngoscope 109(1): 140-147.

12. Nicolai P, Berlucchi M, Tomenzoli D, Cappiello J, Trimarchi M, et al. (2003) Endoscopic surgery for juvenile angiofibroma: when and how. Laryngoscope 113(5): 775-782.

13. Andrews JC, Fisch U, Aeppli U, Valavanis A, Makek MS (1989) The surgical management of extensive nasopharyngeal angiofibromas with the infratemporal fossa approach. Laryngoscope 99(4): 429-437.

14. Chandler JR, Moskowitz L, Goulding R, Quencer RM (1984) Nasopharyngeal angiofibromas: staging and management. Ann Otol Rhinol Laryngol 93(4): 322-329.

15. Radkowski D, McGill T, Healy GB, Ohlms L, Jones DT (1996) Angiofibroma: changes in staging and treatment. Arch Otolaryngol Head Neck Surg 122(2): 122-129.

16. Hackman T, Snyderman CH, Carrau R, Vescan A, Kassam A (2009) Juvenile nasopharyngeal angiofibroma: the expanded endonasal approach. Am J Rhinol Allergy 23(1): 95-99. 
This work is licensed under Creative Commons Attribution 4.0 License DOI: $10.19080 /$ GJO.2017.03.555620

\section{Your next submission with Juniper Publishers will reach you the below assets}

- Quality Editorial service

- Swift Peer Review

- Reprints availability

- E-prints Service

- Manuscript Podcast for convenient understanding

- Global attainment for your research

- Manuscript accessibility in different formats

( Pdf, E-pub, Full Text, Audio)

- Unceasing customer service

Track the below URL for one-step submission https://juniperpublishers.com/online-submission.php 